aflinity of blood for oxyen in patients with lou-output heart fathlure. (in Res., 25: 47 (1969).

19. Morse M Cassels, D E and Holder $M$. The position of the oxseon dissociation curve of the hlowd in chanotic congenital heart disease. I. (lin Invest. 29: $1098(1950)$

20. Oski. I. A.. Gottlieh, A. I. Delivoria-Papadupoulus. M.. and Miller. H. W. Red-cell 2.3-diphosphoglycerate levels in suhjects with chronic hyponemia Engl J Med 280): 1165(196)

21. Oski, F. A. Gotllieb. A.J., Miller. W. W., and Delivoria-Papadopoules, M.: The effect of deoxyenation of adualt and fetal hemogkbin on the synthesis of red cell 2.3-DPG and its in vios consequences. J. (lin. Invest. 49: 400(1970).

22. Riegel. K. P., and Versmold. H.: Postnaltal hlowd orygen transport, with special respect to idiopathic respiraltory distress sindrome. Bu!l. Phusio-Pathol. Resp. 4. $1533(1973)$.

23. Rose. 2. B.: Effect of salts and phlt on the rate of ersthrocyte diphospheglycerate mutasc. Arch. Biochem. Biophys.. 158: 903 (1973)

24. Rosenthal, A.. Mentere, W. C.. Fisenstein, F. B.. Vathan. D. G.. Velsun. N. I1 and Nadas. $A$. S.: The role of red cell organic phosphates in adaptation to congenital heart disease Pediatrics, 47:537 (1971)

25. Turek. Z. Kreuzer, F.. and Hoofd, L. J. C.: Advintage or disadvantages of decrease of blood oxygen alfinity for tissue oxygen supply at hypoxia. Pflieger Arch. Ges. Physiol.. 342: 185 (1973)

26. van Slyke, D. D.. Hastings, A. B.. Murras. ( . D). and Sendros, J.: Studies of gas and electrolyte equilibria of blood. VIII. The distribution of hydrogen, chloride and bicarbonate ions in oxygenated and redued hlood. J. Biol. (hem., 65: 701 (1925)

27. Versmold. H., and Brauser. B.: Improved cellular oxygeration by 2.3-diphosphoglverate: Quantitative measurement of tissue hypoxia by registration of absorption spectra of cytochrome $a$ and hemoglobin in the intact organ. In: $E$. Gerlach, K. Moser and W. Wilmanns. Ersthracies. Thromboctles. I cuco- cytes. P. 170 (Thieme. Stuttgitt. 1973)

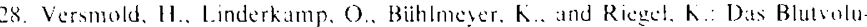
men, die llämoglobinmasse und die arteriellen $\mathrm{O}_{2}$-Parameler bei angeborenen Herstehlern von Sïuglingen und kindern. Michr Kinderheilk., 119:414 (1971).

29. Versmold. H.. Seifert. (j.. and Riegel. K. P.: Blood oxygen affinity in infancy The interaction of fetal and adult hemoglobin. oxigen capacity, and red cel

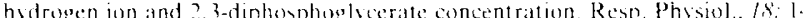
(1973)

30. Versmold. II. Wenner. J.. and Riegel. K. P.: Changes of blowd oxygen affinty and calpalcity and red cell 2,3-diphosphoglycerate choted by exchange transtusion with $\Lambda(D$-preserved blood in newborn infants: Their interrelationship and intluences on oxygen supply of tissues ind erythropoiesis. L. Kinderheilk., //3: I (1) 92 )

31. Woodsun. R. D.: Red cell adaptation to cardiorespiratory disease. Clin Hematol.. 3: 6?7 (1974)

32. Woudson. R. D.. Torrance. J. D. Shapell. S. D.. and I enlant. C.: The effect of

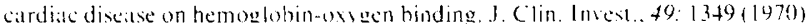

33. Wyman. 1. Heme proteins. Advan. Protein Chem. 4: 407 (1948)

34. We wish to thank Dr. J. Duhm for critical revision of the manuseript. Ms. Heid Windthorst for perfect technicial alssistance, E. Rohrhuber for statistical evaluations, and Ms. Susan E. Shealy for aid in preparing the manuscript.

35. This work was supported by Deutsche Forschungsgemeinschaft (SFB 51 . Klinische Molekularbiologic und Biochemic).

36. P. Irts of this material uere prevented it the Veeting of the Luropeitn Pediatric Respiration Club. Pont-it-.Mousson. September 1973.

37. Requests for reprints should be addressed to: H. Versmold. M.D. Universitäts kinderklinik, D-8 München 2, 1.indw urmstr. 4. Federat Republic of German!

38. Accepted for publication December 3. 1975
Antibiotics

heart

inotropic agent newborn

sympathetic nervous system

\title{
Response of the Neonatal Heart to a New Inotropic Agent, RO2-2985 (X537A)
}

\author{
PAUL. C. GILLETTE, ${ }^{22}$ RONALD G. MUNSON, ROBERT M. LEWIS, AND ARNOLD SCHWARTZ
}

Department of Cell Biophtsics. Division of Mrocardial Biologl, and Department of Pediatrics. Section of Cardislogt, Ballor (ollege of Medicine and the Fondren-Brown Cardiovascular Research and Training C'enter. The Merhodist Hospital. Houston. Texas. LS.A

\section{Extract}

The ionophore $\mathrm{RO} 2-2985$ did not produce a positive inotropic response in 1-day-old canine isolated ventricle. A gradual increase in inotropic response was seen with age. Isolated atria, however, exhibited a positive inotropic response at birth $(50 \%$ increased $\mathbf{d F} / \mathbf{d t})$, which became progressively greater with age $(100 \%$ increase in $\mathbf{d F} / \mathbf{d t}$ at $\mathbf{1 5}$ days of age). In the neonatal heart in situ there was a positive inotropic response in 1-day-old puppies $140 \%$ increase in left ventricular $\mathbf{d F} / \mathbf{d t}$ ) with progressively greater responses with age $(135 \%$ increase in left ventricular $\mathrm{dF} / \mathrm{dt}$ at 11 days of age $)$ There was a positive chronotropic $175-125 \%$ increase) response to RO2-2985 at all ages studied. The drug elevated systemic arterial pressure $(150 \%$ increase in mean arterial pressure) to a similar degree in all ages studied. RO2-2985 depressed total calcium binding by both neonatal and adult isolated cardiac sarcoplasmic reticulum approximately $\mathbf{5 0} \%$.

\section{Speculation}

Although the exact mechanism of action of RO2-2985 on the heart remains unproven, the temporal association of the increase in ventricular and atrial sympathetic nerse endings with development reported by previous authors and the increase in response to RO2-2985 and tyramine suggest that the drug might act in part by releasing a humoral substance. The discrepancy between in situ and isolated studies tends to support this view. A more complete delineation of all subcellular fractions of the developing heart will be necessary to clarify the differential actions of this and other drugs on the developing heart. RO2-2985 may be of value in the treatment of low cardiac output states in neonates as well as adults, but specific testing in neonates will be necessary.

The antibiotic ionophore RO2.2985 (Hofmann-LaRoche), in exerting a significant effect on the cardiovascular system, 
prompted the suggestion of potential therapeutic usefulness $(2,3$. $10,18,19)$. Studies on isolated cardiac tissues have shown an increase in contractile force after administration of RO2-2985 (2. $3,10,18,19)$. This has been confirmed in intact preparations $(2,3$, 18). The heart rate and systemic blood pressure were also increased. Although the exact mechanism of action of RO2.2985 remains unknown, it is known to enhance transport of both mono. and divalent cations as well as biologically active amines across membranes and to promote a calcium proton exchange $(6,14)$. The drug also decreases calcium binding and uptake by isolated cardiac sarcoplasmic reticulum (SR) and rapidly releases calcium that was previously bound to the SR $(4,5,15)$.

All of the published work to date on RO2.2985 has employed adult cardiac tissue. It was the purpose of this study to evaluate the effects of RO2-2985 on the neonatal canine heart in order to obtain further data concerning mechanism of action.

\section{MATERIALS AND METHODS}

Four preparations were used: (1) isolated perfused ventricle, (2) isolated atrium, (3) intact in situ heart, and (4) isolated sarcoplasmic reticulum. All were obtained from mongrel puppies of both sexes whose exact age was known and who had been kept with their mothers until used. RO2.2985 was dissolved in benzyl alcohol. anhydrous alcohol, and propylene glycol. The vehicle alone was used for a control in all experiments. The order of administration of RO2-2985 and tyramine was alternated to decrease the effect of tachyphylaxis. RO2-2985 and tyramine were always given before other drugs. The puppies from each litter were used in series (i.e. for a six-puppy litter, two were studied at each of three ages).

\section{ISOLATED VENTRICULAR PRFPARATION}

The animal was killed by cervical dislocation and the heart was rapidly removed and suspended on a constant flow device (18) at $37^{\circ}$ and perfused via the aortic root with $\mathrm{K}$ rebs solution with the following millimolar concentration: $\mathrm{NaCl} 118, \mathrm{KCl} 4.7, \mathrm{CaCl}_{2} 2.5$ $\mathrm{NaHCO}_{3} 25 . \mathrm{MgCl}_{2} 0.5, \mathrm{NaH}_{2} \mathrm{PO}_{4} 1.0$, and glucose $11.1, \mathrm{pH}$ $7.30-7.40$. The Krebs solution was continuously bubbled with $95 \%$ $\mathrm{O}_{2}: 5 \% \mathrm{CO}_{2}$

The atria were removed. the atrioventricular node crushed, and pacing accomplished by wires placed in the right ventricle at a rate of $120 \mathrm{cpm}$. The atrioventricular valves were excised and the pulmonary artery opened. A Walton-Brodie strain gauge arch (20) was sutured to the free wall of the left ventricle.

Krebs solution prewarmed to $37^{\circ}$ was perfused at a constant pressure of $20 \mathrm{~mm} \mathrm{Hg}$ by an occlusive peristaltic pump. Drugs were administered by changing from one reservoir to another without interrupting flow. Developed force as well as its first deri. vative with respect to time (dF/dt) were continuously recorded on a Grass model 7 polygraph. This equipment and solution are the same as previously described for the cat heart from this laboratory (18). Four preparations were studied at each age.

\section{ISOLATED ATRIA}

After the heart had been perfused, as in the preceding section. the atria were removed and a strip of left atrium was attached by suture to a Statham force transducer $(350 \mathrm{ohms})$ and tension adjusted for maximum force of contraction. Drugs were then added to the solution and mixed by a constant stream of $95 \%$ $\mathrm{O}_{2}: 5 \% \mathrm{CO}_{2}(\mathrm{pH} 7.30-7.40)$. The temperature of the bath was maintained at $37^{\circ}$. Force and $\mathrm{dF} / \mathrm{d}$ t were continuously recorded on the Grass polygraph. Four preparations were studied in each age range.

\section{IN SITU HEART}

The animals were anesthetized with sodium pentobarbital ( 25 $\mathrm{mg} / \mathrm{kg}$ intraperitoneal) and respiration controlled with a Harvard model 606 respirator pump for small animals by way of a tracheostomy. Temperature was continuously monitored and controlled at $37^{\circ}$ by electric heating pads. Arterial blood gases were maintained in the normal range by adjusting the respirator. The carotid artery was cannulated with a short piece of polyethylene tubing directly attached to a Statham P23db strain gauge. A second polyethylene catheter was advanced well into the internal jugular vein for infusion of drugs.

The chest was opened and the heart cradled in the pericardium A strain gauge arch was sutured to the free wall of the lelt ventricle. The preparation was covered with a sheet of polyethylene to prevent excessive evaporation. Electrocardiogram, central aor. tic blood pressure. left ventricular force, and $\mathrm{dF} / \mathrm{dt}$ were continu. ously recorded on a Brush model 200 recorder

Two preparations were studied at I day of age, four preparations at 2.5 days of age, five at 4 days of age, and two at 11 days of age.

\section{ISOL ATED CARDIAC SARCOPLASMIC RETICULUM}

The sarcoplasmic reticulum was isolated as described previously by this laboratory (8). Maternal SR was isolated stimultaneously to serve as a control. A dual-beam spectrophotometric method using murexide as a calcium indicator was used to measure calcium "binding" (in the absence of oxalate) and "uptake" (presence of oxalate) $(4,5,8)$.

\section{RESULTS}

\section{ISOLATED VENTRICULAR PREPARATION}

The inotropic response of isolated ventricles from 1,10 , and 15 days of age to RO2-2985 was evaluated and compared with their response to tyramine, a known catecholamine releaser. There was no increase in the force of contraction of isolated vent ricles up to 2 days of age with either RO2.2985 or tyramine (Fig. 1). Older ventricles responded, and the amount of increase in force of contraction and $\mathrm{dF} / \mathrm{dt}$ was proportional to age (Figs. 1 and 2). The ventricles which would not respond to RO2-2985 or tyramine did increase their force of contraction after administration of norepinephrine, isoproterenol, or ouabain (data not shown).

\section{ISOLATED ATRIA}

There was a positive inotropic response to RO2.2985 and tyramine by the atrium of even the youngest animals studied (Fig. 3). The increased force of contraction to the same concentration was progressively greater at increasing ages (Figs. 2 and 3 ). The
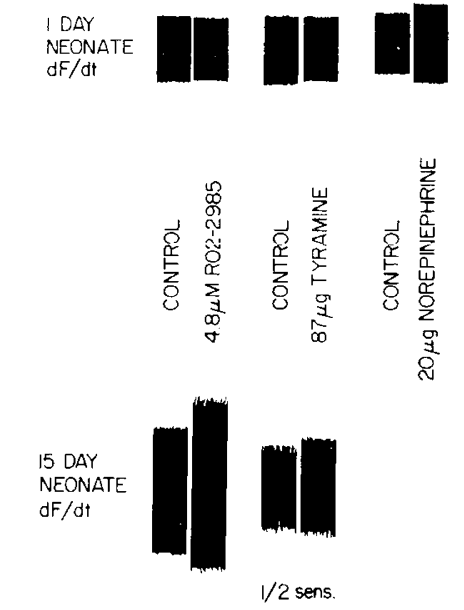

Fig. 1. Maximum response of the isolated perfused developing canine ventricular preparation to RO2-2985 and tyramine at the 1 st day and 15 th day of age. The original tracing of the first derivative of force with respect to time is presented. 

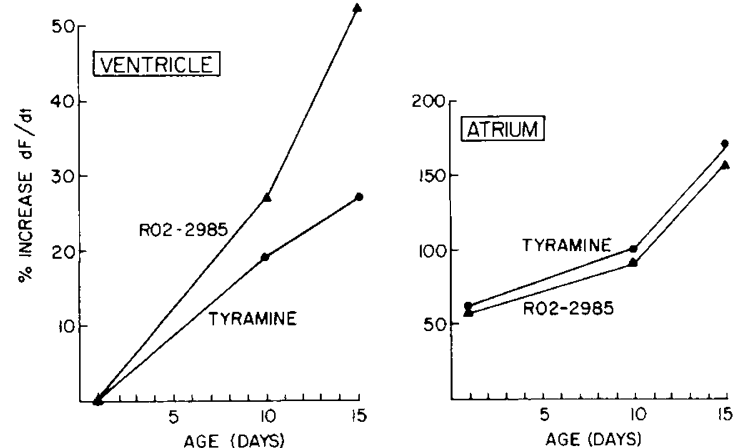

Fig. 2. Graph of the relationship of the maximum positive inotropic response of the developing isolated ventricle and atrium to RO2-2985 and tyramine.
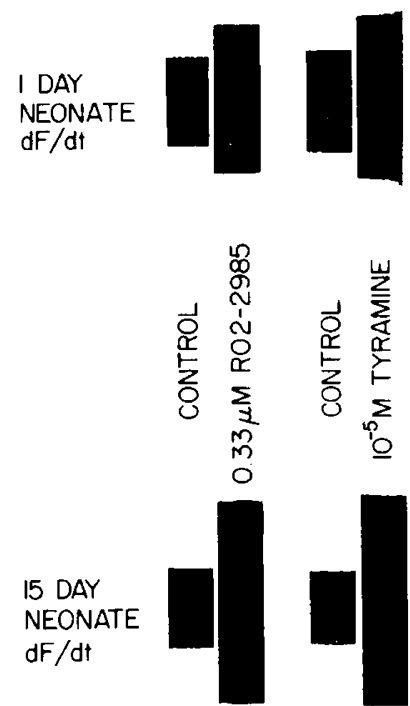

Fig. 3. Maximum positive inotropic response of the developing atrium to $\mathrm{RO} 2-2985$ and tyramine using $\mathrm{dF} / \mathrm{dt}$ as an index of contractility.

magnitude of the atrial response was greater at all ages than that of the ventricle.

\section{IN SITU HEART}

RO2-2985 and tyramine both exerted a positive inotropic response on the in situ left ventricle at 2 days of age (Fig. 4). The response increased with age, reaching essentially adult levels by 12 days of age (Figs. 5 and 6). RO2-2985 produced a 100\% increase in heart rate in puppies from $1 \quad 12$ days of age. There was also a $100 \%$ increase in mean aortic blood pressure in response to RO2.2985 in all ages studied.

In one 7-day-old puppy, a single injection of RO2-2985 produced a $40 \%$ increase in $\mathrm{LVdF} / \mathrm{dt}$ and a $50 \%$ increase in central aortic pressure. After this effect had disappeared and the animal was intentionally put into hypovolemic hypotension (shock) by withdrawing blood until a mean arterial pressure of $25 \mathrm{~mm} \mathrm{Hg}$ was reached, an equal injection of RO2-2985 increased LVdF/dt $230 \%$ and central aortic pressure $150 \%$ (Fig. 7)

\section{ISOI.ATED CARDIAC SARCOPLASMIC RITICULUM}

RO2-2985 depressed calcium binding and uptake of the isolated sarcoplasmic reticulum of 1-, 3--, and 7-day-old neonatal canines to a similar degree as the maternal control. A whole litter of puppies $(6 \quad 10)$ had to be used for each preparation. Each preparation was tested in triplicate and the results averaged. A representative experiment is shown in Figure 8. No difference was noted between the activity of the neonates and maternal controls.

\section{DISCUSSION}

The cardiovascular response in the early postnatal period to RO2.2985 is markedly different than in adult animals. In the intact preparations this difference was manifested in two ways. A $100 \%$ increase in $\mathrm{LVdF} / \mathrm{dt}$ was seen in adult animals after injection of $1 \mathrm{mg} / \mathrm{kg}$ of RO2-2985, whereas in 1- and 2.5-day-old puppies. less than $50 \%$ increase was found. By 12 days of age the positive inotropic response reached the adult level. The isolated ventricle showed no increase in contractile force to RO2-2985 before 3 days of age. This discrepancy between the isolated and in situ preparations was confirmed by studying puppies from the same litter on the same day using both methods. There was no response by the

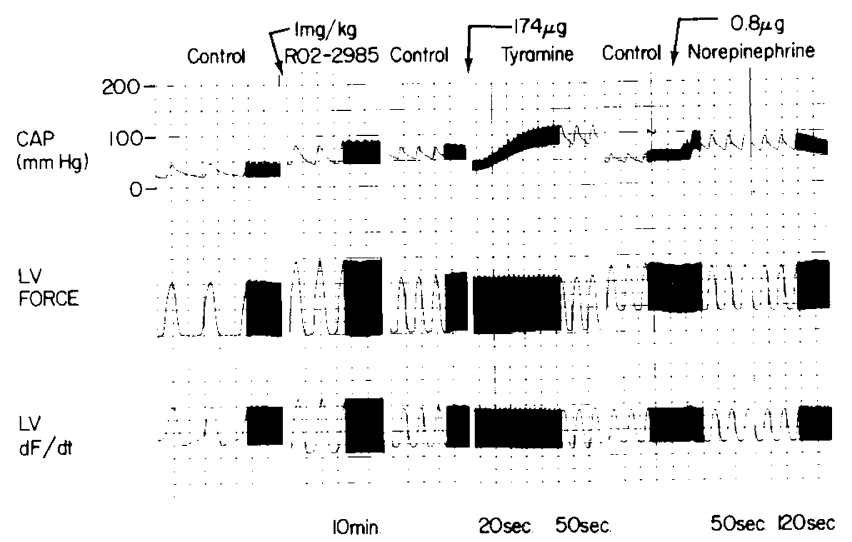

Fig. 4. Hemodynamic effects of RO2-2985 on a 2.5-day-old puppy. From top to bottom: the central aortic pressure (CAP), the left ventricular force and its first derivative. From left to right: control period, maximum effect of RO2-2985 (10 min), return towards control, effect of tyramine, return towards control, effect of norepinephrine.

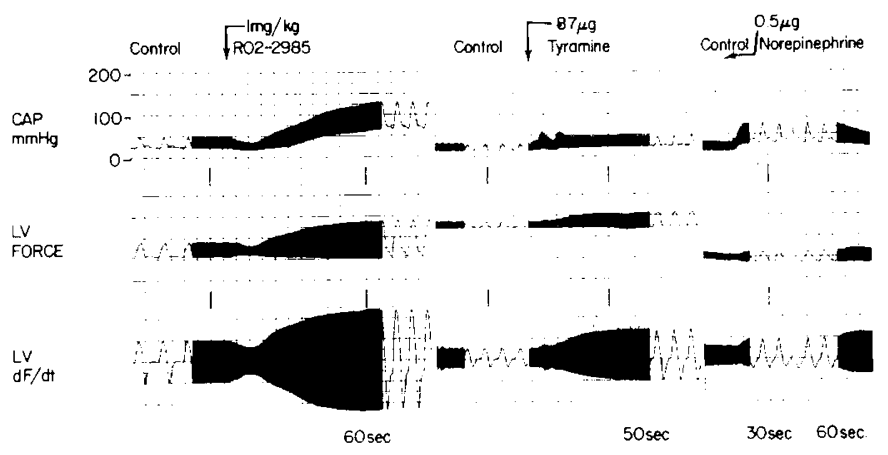

Fig. 5. Hemodynamic effects of RO2-2985 on a 12-day-old puppy Relationship of events the same as in Figure 4

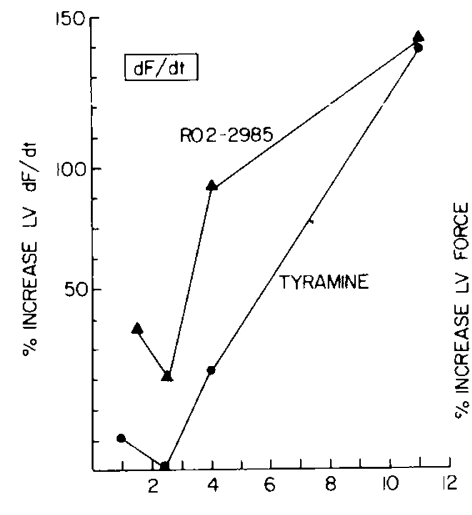

AGE (DAYS)

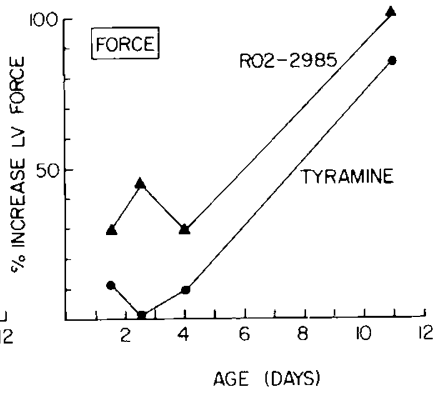

Fig. 6. Graph of the changes with development of the inotropic response to RO2-2985 of the in situ heart using $\mathrm{LVdF} / \mathrm{dt}$ and $\mathrm{LV}$ force as indices of contractility. 


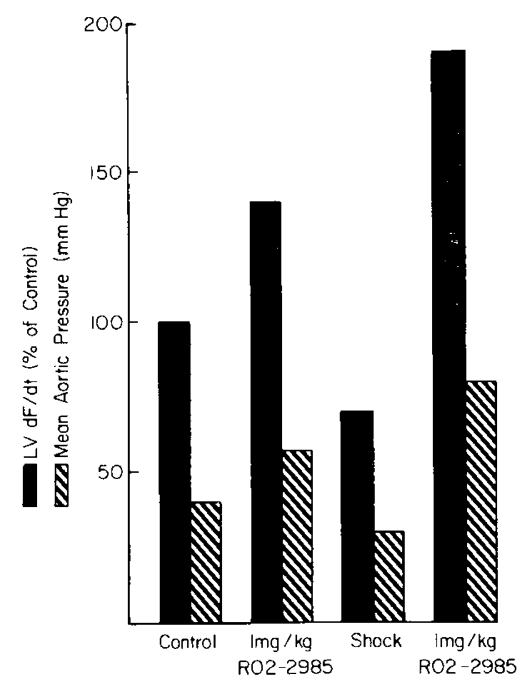

Fig. 7. Changes in $\mathrm{LVdF} / \mathrm{dt}$ and aortic pressure of a 7-day-old puppy exposed to RO2-2985 before and after induction of hypovolemic hypotension ("shock").

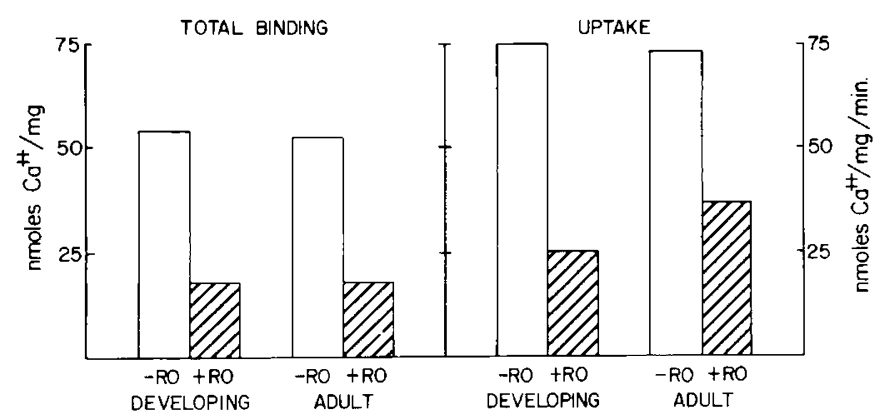

Fig. 8. Effect of RO2-2985 (RO) on calcium binding and uptake of neonatal and adult isolated cardiac sarcoplasmic reticulum. No differential effect of the drug was found

isolated 1.5-day-old ventricle to a concentration of RO2-2985 which stimulated older ventricles. The in situ ventricle, however, exhibited a $48 \%$ increase in $\mathrm{dF} / \mathrm{dt}$. This discrepancy could be explained by either the lack of sympathetic innervation of the isolated ventricle or the absence of some circulating factor. Several investigators have pointed out that the development of the sympathetic nervous system is not complete at birth in several species, including dogs, cats, sheep, rabbits, and swine $(7,12)$.

We postulate that part of the action of RO2-2985 is in some way mediated by sympathetic nerve endings. This could be accom plished by either the ionophore directly "transporting" the hor. mone out of the nerve ending, by transporting calcium and/or sodium into it, or by promoting a calcium proton exchange, as has been suggested for vasopressin release (13). It is of interest that a specific calcium and magnesium ionophore, A23187, has no cardiovascular effect (18). This would explain several aspects of our study. The sympathetic nerve endings are plentiful in the atria at birth, and RO2-2985 and tyramine produced a marked positive inotropic response from birth. The sympathetic nerve endings innervate the ventricles progressively over about the same time period as the increase in response to RO2-2985 and tyramine. The discrepancy between in situ and isolated ventricles could also be due to a "circulating factor(s)" released from the adrenals by RO2-2985. The transporting ability of RO2-2985 for biologically active amines is also in support of this contention (14). The fact that reserpinized preparations do not exhibit a positive inotropic response to RO2-2985 (18) supports but does not prove our contention, inasmuch as reserpine has many actions (17). The failure of propranolol to block the inotropic response to RO2-2985 (18) is against a mechanism of action directly involving the $\beta$-receptor; however, propranolol is less effective in blocking the action of endogenously released catecholamines than exogenously administered drugs (9). It is also known that $\mathrm{RO} 2.2985$ has marked effects on the peripheral vasculature in adult dogs. It increases renal, coronary, and iliac blood flow significantly without any significant change in mesenteric blood flow $(11,16$, 18). Thus, the cardiac output may be redistributed.

Since the timetable of developments of the cardiac sympathetic nervous system is not known for the human, the actions of the drug may be very different in the neonate $v s$ the adult. If this drug acts by releasing a hormone or some other substance from sympathetic nerve endings, its usefulness in patients with chronic congestive heart failure may be limited, since catecholamines are depleted in this state (1).

\section{SUMMARY}

The neonatal canine heart has been found to be less responsive to the inotropic drug RO2-2985 than the adult heart. The inotropic response to the drug develops with increasing age, reaching adult levels at about 2 weeks of age. This parallel development of response to the drug and previously known completion of sympathetic innervation to the heart suggests that the drug may interact with the sympathetic nervous system.

\section{REFERENCES AND NOTES}

I. Covell, J. W. Chidsey, C. A., and Braunwald, E.: Reduction of the cardiac response to postganglionic sympathetic nerve stimulation in experimental heart failure Circ. Res. 19: 51 (1966)

2. deGuzman, N. T., and Pressman, B. C.: Hemodynamic effects of the ionophore X537A [Abstract]. Circulation, 48: (Suppl. IV), IV 158 (1973)

3. deGuzman, N. T., and Pressman, B. C.: The inotropic effects of the calcium ionophore X537A in the anesthetized dog. Circulation, 49: 1072 (1974).

4. Entman, M. L. Allen, J. C., Bornet, E. P. Gillette, P. C.. Wallick. E. T., and Schwartz, A.: Mechanisms of calcium accumulation and transport in cardiac relaxing system (sarcoplasmic reticulum membranes): Effects of verapamil, D-600, X537A and A23187. J. Mol. Cell. Cardiol., 4: 681 (1972).

5. Entman, M. L. Gillette, P. C. Wallick, E. T., Pressman, B. C., and Schwartz A.: Study of calcium binding and uptake by isolated cardiac sarcoplasmic reticulum: Use of a new ionophore (X537A). Biochem. Biophys. Res. Commun., 48: 847 (1972).

6. Estrada-O, S., Celis, H., Fernandez, M., and Montal, M.: The mode of action of compound X537A: A model calcium translocator in natural and artificial membranes. Polish Symposium, 1973. In: Calcium Binding Proteins, pp. 895919 (Elsevier Scientific Publishing Company, Amsterdam, 1974).

7. Friedman, W. F.: The intrinsic physiologic properties of the developing heart. In W. F. Friedman, M. Lesch, and E. H. Sonnenblick: Neonatal Heart Disease (Grune and Stratton, New York, 1973).

8. Harigaya, S., and Schwartz, A.: Rate of calcium binding and uptake in animal and human cardiac muscle: Membrane (relaxing system) and mitochondria. Circ. Res., 25: 781 (1969).

9. Ledsome, J. R., Linden, R. J., and Norman, J.: The use of sympathet ic $\beta$ receptor blocking agents in the investigation of reflex changes in heart rate. Brit. J. Pharmacol., 24: 781 (1965).

10. Levy, J. V., Cohen, J. A., and Inesi, G.: Contractle effects of a calcium ionophore. Nature, 242: 461 (1973).

11. Lewis, R. M., Hanley, H. G., Hartley, C. J., Franklin, D., and Schwartz, A.: Effects of antibiotic ionophore RO2-2985 on regional blood flow in conscious dogs. Circulation, 45/50: III-36 (1974).

12. Linha, S. N.. Armour. J. A.. and Randall. W. C.: Development of autonomic innervation of the heart [Abstract]. Circulation, 48: (Suppl. IV): IV-37 (1973).

13. Nakazato, Y., and Douglass, W. W.: Vasopressin release from the isolated neurohypophysis induced by a calcium ionophore, X537A. Nature. 249: 479 (1974).

14. Pressman, B. C.: Interaction of divalent ionophores with membrane system. Proceedings of the Fourth International Biophysics Congress, Moscow, August 7-14, 1972

15. Scarpa, A., and Inesi, $G_{\text {.: }}$ Ionophore mediated equilibration of calcium ion gradients in fragmented sarcoplasmic reticulum. Fed. Eur. Biochem. Soc. Lett. 22: 273 (1972)

16. Schwartz, A.. Hanley, H. G., Lewis, R. M., Munson, R., and Dial, F. D.: A new positive inotropic drug RO2-2985/1 (X537A) with potential use in the treatment of cardiac disease [Abstract]. Amer J. Cardiol., 33: 170 (1974).

17. Schwartz, A., and Lee, K. S.: The effect of reserpine on heart mitochondria. Nature, 188: 948 (1960).

18. Schwartz, A. S., Lewis, R. M., Hanley, H. G., Munson, R. G., Dial, F. D., and Ray, M. V.: Hemodynamic and biochemical effects of a new positive inotropic agent Circ Res. 34: 102 (1974).

19. Williamson, J. R.. Schaffer, S. W., Scarpa, A., and Safer, B. Investigation of the calcium cycle in perfused rat and frog heart. In: N. S. Dhalla: Recent Advances 
in Studies on Cardiac Structure and Metabolism, Vol. 4, pp. 375-392 (University Park Press, Baltimore, 1972)

20 John A Warren, Charleston, S. C

21. This research was supported by United States Public Health Service Training Grant HL 05925-04. Research Grant HL 05435-14, and Contract NiH
$71-2493$.

22. Requests for reprints should be addressed to: P. C. Gillette, M.D., Department of Cell Biophysics, Baylor College of Medicine, 1200 Moursund Ave., Houston. Tex. 77025 (USA).

23. Accepted for publication December 15, 1975.
Amylase

calcium

cystic fibrosis

flow rate inorganic phosphate parotid saliva

potassium

sodium

\title{
Parotid Gland Function in Children with Cystic Fibrosis and Child Control Subjects
}

\author{
JEANETTE BLOMFIELD, ${ }^{3:}$ ANNE R. RUSH, HELEN M. ALLARS, AND JOHN M. BROWN \\ Children's Medical Research Foundation and Cistic Fibrosis Clinic, Royal Alexandra Hospital for Children, Sydney, \\ New South Wales, Australia
}

\section{Extract}

Parotid saliva was collected from 22 children with cystic fibrosis (CF) and 21 control children. Stimulation was by $0.1 \mathrm{ml} 5 \%$ citric acid on the tongue every $15 \mathrm{sec}$ over a period of $10 \mathrm{~min}$, and samples were collected for $\mathbf{2}$-min intervals. Stimulated saliva showed a lag period of low amylase release, and an activated period of higher amylase release. The major difference between $C F$ and child control parotid saliva was in the elevated calcium concentrations in $\mathrm{CF}$ subjects. Flow rate and amylase, although higher in the $\mathrm{CF}$ group, were not raised to a statistically significant level. There were higher mean values for sodium and inorganic phosphate in $\mathrm{CP}$ children but statistical significance was minimal. Potassium values were almost identical in $C F$ and control saliva. In the activated parotid saliva samples of both control and $C F$ subjects there were positive correlations between flow rate and calcium, flow rate and sodium, amylase and calcium, and sodium and calcium, and negative correlations between sodium and potassium. The parotid function test has no value as a diagnostic test for cystic fibrosis, as even calcium values show too much overlap with control saliva to be of diagnostic worth.

\section{Speculation}

Higher calcium values in parotid saliva of $\mathrm{CF}$ children are likely to cause increased formation of insoluble calcium-phosphate-protein complexes within the acinar lumina and small ducts of the parotid gland and increased deposition of dental calculus on tooth surfaces adjacent to the openings of the parotid ducts.

In a previous study (5), parotid saliva collected during a short term (4-min) stimulation had shown elevated protein, amylase, and calcium concentrations in cystic fibrosis (CF) parotid saliva compared with control saliva. The higher protein concentrations were associated with colloidal separation of sparingly soluble protein on cooling the saliva to room temperature. Subsequently, parotid saliva with high calcium concentrations has been shown to form turbid calcium-phosphate-protein complexes on standing at body temperature $(1,2)$. It has been suggested that this sparingly soluble material might be causing obstruction in parotid glands of CF patients (22) and excessive dental calculus on their teeth (26)

Previous comparisons of $\mathrm{CF}$ and control parotid saliva have produced conflicting results, showing that, in CF parotid saliva, flow rate is increased $(18)$ or not different $(4,6,13)$, protein is increased $(3,4)$ or not $(16,25)$, amylase is elevated $(3,4)$ or not (15), calcium is raised $(3,4,6,18,25)$ or not $(16,18)$, sodium is higher $(4,6,12,18)$ or not $(16)$, inorganic phosphate is increased $(4,6,16)$, and potassium is not different from controls $(4,6,12,16$, 18).

However, studies by Dawes $(8,9)$ of parotid saliva of normal subjects have shown that stimulated saliva takes approximately 3 min to change from a resting to an activated state, that variation of degree of sucking lozenges influences flow rate, that flow rate influences concentrations of protein and electrolytes, and that the duration of stimulation also influences concentrations of protein and calcium. Therefore, many of the previous studies of CF saliva are difficult to interpret. Thus variation among both $\mathrm{CF}$ and control children in rates of chewing chicle (6), or sucking lozenges $(16,18)$ or citric acid crystals $(12)$ would affect results randomly. In other studies, collection times were variable among subjects (6), were not stated $(15,25)$, or were short $(3,4)$.

In the present study, the stimulus was constant and operator controlled, and the effects of duration of stimulation were assessed by 2 -min sampling over a 10 min period. Correlations between flow rate, amylase, and inorganic components were determined in the activated saliva collected between 4 and 10 min after commencing stimulation.

\section{SUBJECTS AND METHODS}

Parotid saliva was collected from 22 children with cystic fibrosis (13 male and 9 female, with a mean age of 9.2 years and range of 6-13 years) who were attending the Cystic Fibrosis Clinic at the Royal Alexandra Hospital for Children as outpatients. There were 21 control children ( 13 male and 8 female, with a mean age of 9.2 years and range of 5-13 years), who were children of members of staff and their friends. Informed consent was obtained for all subjects. 